\title{
Influence of Environmental Factors on Tree Species Diversity and Composition in the Indian Western Himalaya
}

\section{Shinny Thakur}

Govind Ballabh Pant National Institute of Himalayan Environment and Sustainable Development

\section{Rupesh Dhyani}

Institut national de la recherche scientifique

Vikram S Negi ( $\square$ vikramsnegii@gmail.com)

Govind Ballabh Pant National Institute of Himalayan Environment and Development https://orcid.org/0000-0002-3380-7930

\section{D Bhatt}

Govind Ballabh Pant National Institute of Himalayan Environment and Sustainable Development A K Yadava Kumaun University

\section{Research}

Keywords: Forest composition, Plant diversity, Distribution pattern, Environmental factors, Altitudinal gradient, Anthropogenic pressure

Posted Date: May 25th, 2021

DOl: https://doi.org/10.21203/rs.3.rs-542937/v1

License: @ (i) This work is licensed under a Creative Commons Attribution 4.0 International License. Read Full License

Version of Record: A version of this preprint was published at Forest Ecology and Management on January 1st, 2022. See the published version at https://doi.org/10.1016/j.foreco.2021.119746. 


\section{Abstract}

Understanding patterns and forest communities and its driving factors play a critical role in ecological studies. In view of this, present study attempted to understand the role of environmental and anthropogenic factors in relation to species diversity and composition along the altitudinal gradient (700$4000 \mathrm{~m}$ asl) in Indian western Himalaya. A total of 51 tree species (28 families) were recorded; pinaceae (5) and fagaceae (5) were the species rich families. a-diversity indices i.e., Margalef's richness index (R), Shannon index $(\mathrm{H} \otimes)$ and Simpson index showed a humped shaped distribution, whereas Evenness index (E) showed an inverted humped shaped distribution along the altitude range. Based on non-metric dimensional scaling (NMDS), four different community types were identified. Redundancy analysis (RDA) revealed a strong relationship of tree species composition with environmental (41.73\% variation) and anthropogenic factors (17.35\% variation). RDA further indicated that the bulk density (BD), disturbance index (DI), mean diurnal temperature range (Bio2) and solar radiation (SR) are significantly associated with sub-tropical (below $1200 \mathrm{~m}$ ) and lower temperate forest (1200-1700 m) types. Likewise, soil organic carbon (SOC), precipitation of the driest quarter (Bio17) and pH were significantly associated with upper temperate (1700-2900 $\mathrm{m}$ ) and subalpine forest composition (<2900 m). Both NMDS classification and RDA ordination clearly demonstrate spatial variability in composition of tree community and environmental properties.

\section{Introduction}

The importance of mountains for biodiversity and sustaining ecosystem services, has been recognized for long specifically in the aftermath of Rio Earth Summit (1992) when Chapter 13 Agenda 21 (1992) established mountains as an important habitat that support all forms of living organisms (UN 1992). Mountains are home to $50 \%$ of global biodiversity hotspots, and support approximately one-quarter of world's terrestrial biological diversity (Spehn et al., 2010; Price et al., 2011). Among others, the Himalaya has been recognized as one of the globally important biodiversity hotspots that encompasses world's most diverse montane environment, characterized by high diversity of both plant communities and species (Kala et al., 2002; Oommen and Shanker, 2005; Rawal et al. 2013; Boscutti et al., 2018; Negi et al. 2019).

Indian Himalayan Region (IHR) represents a large part of Himalayan Biodiversity Hotspot, where richness, representativeness, and uniqueness of biodiversity components (at gene, species and ecosystem levels) are well recognized (Rawal et al. 2013). Further, IHR is well known for diversity of forest types across its horizontal and vertical extent with $41.47 \%$ of total forest cover of the country. The composition of forest community and distribution of plant species in the region is the refection of environmental gradients (Chawla et al., 2008; Chian et al., 2016; Gómez-Díaz et al., 2017; Ahmad et al., 2020). The spatial variation of biodiversity along altitudinal gradients is one of the basic issue and important aspect in biodiversity research in IHR (Rawal et al. 2018). The higher species diversity in the region is broadly characterized by physiography, climate, soil, and anthropogenic disturbance (Shah et al., 2011). As such, forest in the Himalaya are reported vulnerable to climate change and subjected to severe ecological deterioration due 
to anthropogenic pressures (Upgupta et al., 2015; Chakraborty et al., 2016; Sharma et al., 2017; Negi et al. 2018a; Thakur et al., 2020). Studies have demonstrated that anthropogenic activities are responsible to change the species richness, diversity, and distribution patterns, and subsequently influence the edaphic and environmental conditions (Ahmad et al., 2018; Wang et al., 2019).

Among various ecological parameters, plant species diversity has attracted particular attention because of its applicability in assessing current species performance and predicting future community composition (Wang et al., 2008). Especially, assessment of forest community structure and composition in mountain ecosystem is very helpful in conservation and management planning (Körner, 2007; Chawla et al., 2008; Chian et al., 2016; Gómez-Díaz et al., 2017; Lopez-Angulo et al., 2018; Negi et al. 2018b; Ahmad et al., 2020). Majority of the earlier studies focuses on species composition and vegetation distribution in the different locations i.e., Dhauldhar mountain in Himachal Pradesh (Ahmad et al., 2020), Bhabha valley (Chawla et al., 2008), Uttarakhand Kumoun Himalaya (Rawal \& Pangtey 1994); Garhwal region (Hussain et al., 2008; Sharma et al., 2018; Negi et al. 2018a,b; Rawal et al. 2018),

Khangchendzonga landscape in Sikkim (Sinha et al., 2018), east Nepal (Bhattarai and Vetaas, 2003), and central Nepal (Bhatta et al., 2018) of the Himalayan regions. However, the patterns of plant diversity across altitudinal gradient in relation to environmental and anthropogenic factors are less known in the Himalayan region. Therefore, present study aim to address the following research questions: (i) how the composition and structure of tree communities vary along altitudinal gradient? and (ii) what environmental and anthropogenic factors influence the pattern of community composition and diversity along the altitude?.

\section{Material And Methods}

\subsection{Study area}

The district Pithoragarh in Uttarakhand (western Himalaya), India covers 7,090 sq km area and ranges from 436 to $7117 \mathrm{~m}$ asl in altitude, forms the broad study area (Fig. 1a). The study area comprises with 505 sq km under Very Dense Forest (VDF), 965 sq km under Moderately Dense Forest (MDF) and 609 sq $\mathrm{km}$ under Open Forest (OF) according to FSI (2019). The study area shares international boundaries with Tibet (Autonomous Region of China) and Nepal. This region is an important ecological landscape with varied topography ranging from outer Siwalik to inner high Himalaya represented with diversity of vegetation and forest types covering subtropical to alpine vegetation (Champion and Seth, 1968). As for most of west Himalaya, the study area is attitudinally divisible into subtropical (300 to $1500 \mathrm{~m}$ ), temperate $(1500$ to $3500 \mathrm{~m})$ and alpine $(>3500 \mathrm{~m}$ ) zones according to Saxena et al. (1984). During the winters (December-January), the sub-tropical and temperate mountain ridges receive snowfall and having average temperature range between $5.5-8.0^{\circ} \mathrm{C}$ (Fig. 1b).

\subsection{Vegetation survey and measurement of anthropogenic factors}

Along the altitude range between $700-4000 \mathrm{~m}$ asl, a total of 37 forest sites were investigated based on previous studies from the region (Negi et al. 2018a, 2019; Rawal et al. 2018; Thakur et al. 2020). 
Vegetation assessment in each targeted forest sites were conducted using three randomly placed (50 $\mathrm{x}$ $50 \mathrm{~m})$ stands. In each stand, 5 quadrats $(10 \mathrm{~m} \times 10 \mathrm{~m})$ were laid randomly for enumerating tree species. Vegetation data was generated to assess frequency, density and abundance following the standard phyto-sociological approaches (Misra, 1968, Muller Dombois and Ellenberg, 1974; Negi et al. 2018a; Rawal et al. 2018). Quadrat data of each stand was pooled to estimate tree species richness. The $a$ diversity indices; Margalef's richness index (R), Shannon index $(\mathrm{H} \mathbb{\mathrm { V }})$, Simpson index (I), and Evenness index (E) was calculated in 'vegan' package using R following Oksanen et al. (2019) and their detail description is given in Table 1. Lopping intensity (LI) and cut stump intensity (CSI) was used as a indication of anthropogenic disturbance. Cut stump intensity was determined following Murali et al. (1996), and lopping intensity was calculated following Rawal et al. (2012). Both the disturbance indicators were calculated for each stand and then averaged to make it representative for a particular forest. After calculation of CSI and LI, disturbance index was calculated following Rawat (2013). The intensities of cut-stump and lopping were given weightage values, so that index can be developed. The average of the weightage value of CSI and LI formed disturbance index (DI) for a particular forest.

\subsection{Environmental data}

A total of 36 environmental variables were used to determine linkage with species composition and diversity as an explanatory variable, which represent physiographic, climate, anthropogenic and soil (supplementary Table S1). The data of physiography variables, which describe geographic complexity and regulate species diversity at local and regional scales were downloaded from https://ta.cr.usgs.gov/ and extracted for each sampling site following Moeslund et al., (2013). The bioclimatic variables were extracted for each sample location from global high resolution $\left(\sim 1 \mathrm{~km}^{2}\right)$ database www.worldclim.org. The high resolution $(\sim 250 \mathrm{~m})$ soil variables were extracted from www.soilgrids.org. Correlation analysis was performed among all environmental variables (Fig. 2).To avoid collinearity among the environmental variables multi-collinearity test were performed. To identify collinear environmental variables variance inflation factor (VIF), which defied proportion of variance in one predictor explained by all the other predictors in the model was calculated for each variables (Zurr et al., 2010). A VIF $=1$ indicates no collinearity, whereas increasingly higher values suggest increasing multicollinearity.

\section{Statistical analysis}

\subsection{Non-metric Dimensional Scaling (NMDS)}

NMDS is an unconstrained ordination approach, which produces an ordination based on a distance or dissimilarity matrix. NMDS attempts to represent, as closely as possible, the pair wise dissimilarity between plant communities in a low-dimensional space (Minchin, 1987). The aim of NMDS is to represent the position of plant communities in the multidimensional space as accurately as possible using a reduced number of dimensions that can be easily visualized. The main aim is to recognize and interpret patterns and find gradients for underlying geographical, ecological conditions. Bray-Curtis dissimilarity values, calculated on untransformed species abundance data by the 'vegdist' function from 
the vegan package, were used in the NMDS. Permutational Multivariate Analysis of Variance (PERMANOVA) post hoc tests using Bray-Curtis dissimilarity were performed with the vegan 'adonis' function to quantify the significant difference among the four forest types produced by NMDS. Pairwise comparisons on the dissimilarity between each forest types also used the 'adonis' function, with adjustments for multiple comparisons using the 'p. adjust' function with the 'holm' method (Holm 1979). Significant testing of the sites was done with the vegan 'permutest' function, using 999 permutations.

\subsection{Canonical Redundancy Analysis (RDA)}

The study investigated community ecology quantitative classification; ordination are widely used to understand the relationship between communities and their environment. Redundancy Analysis (RDA) is a method to extract and summarise the variation in a set of response variables (e.g. species abundance data) that can be explained by a set of explanatory variables (e.g. environmental data). This can also be done by NMDS but relating environmental variables to the distances in an NMDS ordination can mislead the interpretation. Typically, this technique represents an approximate of a distance matrix. Therefore, constrained ordination was done for understanding species composition and environmental variables using RDA (Borcard, Gillet \& Legendre 2011) and implemented by the 'decostand' and 'rda' functions from the vegan package. The RDA used forest type and abundance data (both Hellinger-transformed) was considered response variable (Legendre \& Gallagher 2001), and a minimal set of environmental and anthropogenic variables as explanatory variables. To obtain the minimal explanatory set of these variables, a forward selection procedure was used and implemented by the 'forward.sel' function from the 'packfor' package (Dray, Legendre \& Blanchet 2013). The selected variables were additionally validated by a second forward selection procedure, using the vegan 'ordistep' function.

Variance inflation factors (Borcard, Gillet \& Legendre 2011) were calculated on the variables from the RDA using the vegan 'vif.cca' function to identify whether any of the selected variables were redundant. Permutation testing of the RDA model was done using the vegan 'permutest' function with 99999 permutations.

\section{Results}

\subsection{Species diversity pattern and characteristics}

Tree species diversity along altitudinal gradient showed differences in species diversity indices. In general, the Shannon diversity index $\left(\mathrm{H}^{\prime}\right)$ showed humped shaped pattern along the altitude with maximum diversity at mid-altitude zone (Fig. 3a); species richness also followed the similar pattern (Fig. 3b). Species diversity, increased with an increase in species richness i.e., the level of species diversity depended on the richness of species composition. The trend in the dominance index contrasted with that of the diversity index and played close relationship with the number of dominant species. Dominance and evenness varied from 0.17 to 1 and 0.39 to 1 , respectively (Fig. 3c \& 3d), and showed inverted humped shaped pattern. The highest species diversity and richness was recorded at mid altitude ranges, whereas evenness and dominance first decreased and then increased with increasing altitude (Fig. 3a-d). Among 
the different forest types, the maximum average Shannon diversity index $\left(\mathrm{H}^{\prime}\right)$ was observed in upper temperate forest $(1.25 \pm 0.10)$, and minimum $(0.25 \pm 0.15)$ in subalpine forests (Fig. 4a). Similarly, species richness was higher $(5.8 \pm 0.58)$ in upper temperate forest, whereas minimum $(1.75 \pm 0.25)$ in subalpine forest (Fig. $4 b)$. Species dominance index was recorded higher $(0.83 \pm 0.11)$ in subtropical forest and lowest $(5.8 \pm 0.58)$ in upper temperate forest type (Fig. $4 \mathrm{C})$. Tree species evenness was higher $(0.79 \pm 0.11)$ in subalpine forest and lower $(0.64 \pm 0.04)$ in upper temperate forest (Fig. $4 \mathrm{~d})$.

\subsection{Community composition and classification}

Across 37 studied forest sites, a total of 51 tree species falling in 28 families were recorded; highest number of species was recorded in family Pinaceae (5). Pinus roxburghii with dominance in 14 (37.8\%) forest sites exhibits clear dominance in the region. Quercus leucotrichophora $(5 ; 13.5 \%)$, Betula utilis (4; $10.8 \%$ ) and Pinus wallichiana $(3 ; 8 \%)$ are other dominants species. The details of sites with species composition are provided as supplementary Table S2. Non-metric multidimensional scaling (NMDS) of the sites produced group and separated all the sites into four different forest communities across the altitude (Fig. 2). These include (i) lower zone with subtropical climate (altitude below $1200 \mathrm{~m}$ ), (ii) middle zone with lower temperate climate (1200-1700 m), (iii) upper zone with cool temperate climate (1700-2900m) and (iv) subalpine (above 2900m; Fig. 2). PERMANOVA tests supported that the difference in the different group is significant (PseudoF $=10.16, R^{2}=0.48, p<0.001$ ).

\subsection{Environmental and anthropogenic attributes of species composition}

Constrained ordination using canonical redundancy analysis (RDA) also grouped all the sites in similar fashion as in NMDS. The RDA diagram formed a set of linkages of different forest types along with the environmental factors. Selection of variables for canonical redundancy analysis (RDA) was done by two different forward selection procedures. The variance inflation factors (VIF), which give a measure of the collinearity of each variable with other variables, were low for variable having VIF $<5$ (Supplementary Fig. 1). The RDA1 and RDA2 accounted $41.73 \%$ and $17.35 \%$ variance explained by environmental factors and tested significant using permutation test. Also, the amount of variance of the species is explained by the explanatory variables $\left(R^{2}=0.59\right.$; adjusted $\left.R^{2}=0.31 ; p<0.001\right)$. The grouping of sites was explained together by combination of soil, climate and anthropogenic variables (Fig. 5). The association of species was tested by ANOVA function in RDA. The results revealed, subtropical and lower temperate forests were significantly $(p<0.001)$ associated with variables: BD, DI, Bio2 and SD, whereas similar association of upper temperate and subalpine forests was apparent with SOC, Bio17 and pH (Fig. 5).

\section{Discussions}

\subsection{Forest structure and tree species diversity pattern}

Species richness and diversity are well established parameters of community structure and any changes in these parameters can be used as an indicator of change in community dynamics (Korner 2007; Brinkmann et al., 2009; Zhang and Dong 2010). Spatial variations in species diversity showed significant 
characteristics of vegetation patterns in the studied area. The results exhibited that patterns of tree species diversity are related to both large-scale (climate) and small-scale variables (anthropogenic and soil). These variables together determined assemblages of local communities and distribution of species in given space. The humped shaped responses of tree species richness along altitudinal gradient is in line with previous studies from the Himalayan region (Grytnes and Vetaas, 2002; Bhattarai and Vetaas, 2003; Chawla et al., 2008; Dar and Sundarapandian, 2016; Saikia et al., 2017; Bhatta et al. 2018; Sharma et al., 2019; Ahmad et al., 2020). The variation in species diversity and richness might be due to spatial heterogeneity of habitats within different study plots. Low species diversity at lower altitudes might be attributed to higher anthropogenic disturbances and localization of non-native species (Zhang et al., 2016; Ahmad et al., 2018; Rawal et al. 2018). Significant influence of anthropogenic disturbance on species diversity is well established (Newbold et al., 2015, Ahmad et al., 2020).

Low species diversity towards higher altitudes is attributed to harsh environmental conditions that cause physiological stress to the plants (i.e., low temperature, low rainfall), limiting plant growth and their regeneration (McCain, 2007; Körner et al., 2011; Lee et al., 2013; Gómez-Díaz et al., 2017). Further, plants at higher altitudes are reported to have short growing season, and low ecosystem productivity as compared to the plants at lower altitude (Körner, 2003; Körner, 2007). Occurrence of maximum species at mid-altitudes is significantly correlated with availability of water, optimum temperature, rainfall, etc., which is required for better survival and growth performance (Grytnes and Vetaas, 2002; Bhattarai and Vetaas, 2003; Zhang et al., 2016).

\subsection{Classification of community composition}

The knowledge of plant functional types is very important for differentiating forest communities. This study quantitatively classified and grouped forest community along altitudinal gradients. The community were divided into four groups includes subtropical, lower temperate, upper temperate and subalpine. NMDS analysis showed marked significant differences in tree composition along altitudinal gradients. A clear succession shift in community composition from subtropical to subalpine zone was observed. These four forest communities corresponded to the altitudinal gradient, hence, reiterated the importance of altitude as a covariate to determine the composition of tree species in the region (Fig. 2). This suggests that tree species composition changes with altitude, and demonstrate the role of various environmental factors in dispersion of these forest communities. Similar results have been reported from eastern Himalaya (Sharma et al., 2018). The changes in forest composition might be due to the fact that 'the time needed to recover species composition is longer than to recover species richness' (Lebrija-Trejos et al. 2011; Rozendaal et al. 2019).

\subsection{Influence of environmental variables on communities composition}

As reflected by RDA analysis, variables such as climate, soil and anthropogenic disturbance together played a significant role in determining species composition along altitudinal gradient. Subtropical and temperate forests gets negatively impacted by environmental variables such as bulk density, disturbance index, mean Diurnal Temperature Range (Bio2) and Solar Radiation (SR), whereas upper temperate and 
subalpine forest types get positively influenced by soil organic carbon, precipitation of the Driest Quarter (Bio17) and pH. For example, the RDA analysis showed that subtropical and temperate forests preferred low bulk density (Zheng et al., 2017), which might be due to the variation in bulk density, that indicates low soil porosity and soil compaction. This has been reported to cause restrictions to root growth, and poor movement of air and water there by affecting tree species in tropical forests (Sarvade et al., 2016).

These forests in the region experienced high level of human pressure. Lopping of tree for leaf fodder and fuelwood collection were the main anthropogenic pressure which cause large-scale disturbance in these forests; however, other practices such as logging, cutting and grazing also exist. Earlier studies have reported implications of fuelwood collection and fodder harvesting on species richness of the subtropical and temperate forests in western Himalaya (Rawal et al. 2012; Negi and Maikhuri 2017, 2018a) and across the globe (Ramírez-Marcial et al. 2001; Williams-Linera \& Lorea 2009; Gibson et al. 2011). Anthropogenic disturbance is likely to regulate the community distribution pattern and certainly modifies natural ecosystem process by changing the land use pattern (Newbold et al. 2015; Panda et al. 2019). The vulnerability of a particular species or forest is primarily dependent on the intensity of disturbance (Thakur et al. 2020). Composition of tree species in subtropical and temperate forest gets affected by disturbance index and Bio2.

The range of diurnal temperature is an important indicator of climate change (Karl et al., 1991; Braganza et al., 2004; Qu et al., 2014; Yang et al., 2016) as it influence physiological attributes such as photosynthesis, respiration, reproduction, etc. Mean diurnal temperature range in the present study was found significantly associated with species composition in subtropical to temperate forests. The altitude, precipitation and temperature variables were found highly collinear. Diurnal temperature variation associated with solar radiation and photoperiod, has been reported to regulate plant functions, including central carbon metabolism, stomatal opening, and photoperiodism (Michael et al., 2003; Hu et al., 2019).

The soil organic carbon was important factor that impacted plant species composition of temperate and subalpine forest in the study area. As such, plant functional traits are highly related to soil organic carbon stock and carbon sequestration that influences plant diversity and composition (Jobbágy and Jackson, 2000; De Deyn et al., 2008; Stein et al., 2014; Stark et al., 2017). The intensity and durability of rainfall is reported to have impenetrable effect on local plant diversity and vegetation composition. Bio17 (Precipitation of the Driest Quarter) showed a negative relationship with tree species composition towards high altitude. The water stress during dry season also played a critical role in tree species composition. Earlier studies from the region have indicated that precipitation is important for determining plant species richness and composition in west Himalaya (Panda et al., 2017, 2019). Annual rainfall and its seasonal variation is reported to regulate temporal conditions of plant functional traits i.e., leaf flushing and flowering (Eamus 1999). Higher impact of mean annual precipitation on species richness pattern in the tropics is well reported (O'Brien 1993; Leigh et al. 2004; Davidar et al. 2005). Close association of soil pH with Upper temperate and subalpine forest types can be explained with the reported implications of soil $\mathrm{pH}$ in leaching of micronutrients, which changes the nutrient balance among plant tissues (Drenovsky et al., 2004; Partel et al., 2004 ; Fontaine and Barot, 2005; Clark et al., 2007). 
Cation exchange capacity under the influence of soil pH affects plant diversity through changing $\mathrm{N}$ availability (Partel et al., 2000, 2004; Stein et al., 2014).

\section{Conclusions}

The study provides a comprehensive and quantitative understanding of species richness, diversity and composition of forests focusing on tree species along altitudinal gradient (700 m to $4000 \mathrm{~m}$ ) in western Himalayan particular and Himalayan region in general. The diversity patterns showed a humped shaped response, which is largely explained by the mid-domain effect. Composition of tree species in four distinct community types has been explained together by environmental factors i.e., climate, soil and anthropogenic variables. The environmental variables i.e., bulk density, disturbance index, mean Diurnal Temperature Range (Bio2) and Solar Radiation (SR) negatively influenced composition of other two Subtropical and lower temperate forests, while upper temperate and subalpine forests significantly get associated with soil organic carbon, Bio17 and pH. Anthropogenic pressure in low altitude has facilitated invasion by alien species and consequently result in lesser richness and regeneration of tree species. Overall, this study suggests that tree species diversity and forest composition in the mountainous region is dependent on combined effect of anthropogenic disturbance, soil and climate.

\section{Declarations}

\section{Ethics approval and consent to participate: Not applied}

Availability of data and material: All the data presented in the manuscript and other as supplementary material

\section{Consent for publication: Not applied}

Competing interests: The authors declare that they have no competing interests.

\section{Author contributions:}

IDB: Conceptualization of the study, ST \& RD: Methodology, Software, Validation, ST: Writing- Original draft preparation, Supervision: AKY, Writing- Reviewing and Editing: VSN; All authors read, provided inputs and approved the final manuscript.

\section{Funding:}

Funding from Department of Science and Technology (DST), Govt. of India under NMSHE - Task Force 3 (DST/SPLICE/ CCP/NMSHE/TF/GBPIHED/2014 [G] dated 2/09/14), is gratefully acknowledged.

\section{Acknowledgement}


The authors are thankful to G.B. Pant National Institute of Himalayan Environment (NIHE), Kosi-Katarmal, Almora for facilities. All the authors are highly thankful to late Dr. R.S. Rawal for conceptualization of the study, guidance and encouragement.

\section{References}

1. Ahmad M, Uniyal SK, Singh RD (2018) Patterns of alien plant species richness across gradients of altitude: analyses from the Himalayan state of Himachal Pradesh. Tropical Ecology 59(1):35-43

2. Ahmad M, Uniyal SK, Batish DR, Singh HP, Jaryan V, Rathee S, Sharma P, Kohli RK (2020) Patterns of plant communities along vertical gradient in Dhauladhar Mountains in Lesser Himalayas in NorthWestern India. Science of The Total Environment 716:136919

3. Bhatta KP, Grytnes JA, Vetaas OR (2018) Scale sensitivity of the relationship between alpha and gamma diversity along an alpine elevation gradient in central Nepal. J Biogeogr 45(4):804-814

4. Bhattarai KR, Vetaas OR (2003) Variation in plant species richness of different life forms along a subtropical elevation gradient in the Himalayas, east Nepal. Glob Ecol Biogeogr 12(4):327-340

5. Borcard D, Gillet F, Legendre P (2011) Numerical ecologywith R. Springer, New YorkBouchard M, Pothier D, Gauthier S (2008) Fire return intervals and tree species succession in the North Shore region of eastern Quebec. Can J For Res, 38, 16211633

6. Boscutti F, Casolo V, Beraldo P, Braidot E, Zancani M, Rixen C (2018) Shrub growth and plant diversity along an elevation gradient: Evidence of indirect effects of climate on alpine ecosystems. PloS one 13(4):e0196653

7. Braganza K, Karoly DJ, Arblaster JM (2004) Diurnal temperature range as an index of global climate change during the twentieth century. Geophysical research letters, 31(13)

8. Brinkmann K, Patzelt A, Dickhoefer U, Schlecht E, Buerkert A (2009) Vegetation patterns and diversity along an altitudinal and a grazing gradient in the Jabal al Akhdar mountain range of northern Oman. J Arid Environ 73(11):1035-1045

9. Chakraborty A, Joshi PK, Sachdeva K (2016) Predicting distribution of major forest tree species to potential impacts of climate change in the central Himalayan region. Ecological engineering 97:593609

10. Champion SH, Seth SK (1968) A revised survey of the forest types of India. A revised survey of the forest types of India.

11. Chawla A, Rajkumar S, Singh KN, Lal B, Singh RD, Thukral AK (2008) Plant species diversity along an altitudinal gradient of Bhabha Valley in western Himalaya. J Mt Sci 5(2):157-177

12. Chian YS, Yeh CL, Wang CC (2016) Variation in Mountain Vegetation Composition between the East and the West Sides of Southern Taiwan. Forests 7(8):179

13. Clark CM, Cleland EE, Collins SL, Fargione JE, Gough L, Gross KL, Pennings SC, Suding KN, Grace JB (2007) Environmental and plant community determinants of species loss following nitrogen enrichment. Ecology letters 10(7):596-607 
14. Dar JA, Sundarapandian S (2016) Patterns of plant diversity in seven temperate forest types of Western Himalaya, India. Journal of Asia-Pacific Biodiversity 9(3):280-292

15. Davidar P, Puyravaud JP, Leigh EG Jr (2005) Changes in rain forest tree diversity, dominance and rarity across a seasonality gradient in the Western Ghats, India. \Journal of Biogeography 32(3):493-501

16. De Deyn GB, Cornelissen JH, Bardgett RD (2008) Plant functional traits and soil carbon sequestration in contrasting biomes. Ecology letters 11(5):516-531

17. Dray S, Blanchet FG, Legendre $P$ (2013) packfor: Forward selection with permutation (Canoco p. 46), version 0.0-8/r109. Website http://R-Forge. R-project. org/projects/sedar

18. Drenovsky RE, Vo D, Graham KJ, Scow KM (2004) Soil water content and organic carbon availability are major determinants of soil microbial community composition. Microbial ecology 48(3):424-430

19. Eamus D (1999) Ecophysiological traits of deciduous and evergreen woody species in the seasonally dry tropics. Trends Ecol Evol 14(1):11-16

20. Fontaine S, Barot S (2005) Size and functional diversity of microbe populations control plant persistence and long-term soil carbon accumulation. Ecol Lett 8(10):1075-1087

21. Forest Survey of India, State of Forest Report 2019. Ministry of Environment and Forests, GOI, FSI, Dehra Dun

22. Gibson L, Lee TM, Koh LP, Brook BW, Gardner TA, Barlow J, Peres CA, Bradshaw CJ, Laurance WF, Lovejoy TE, Sodhi NS (2011) Primary forests are irreplaceable for sustaining tropical biodiversity. Nature 478(7369):378-381

23. Gómez-Díaz JA, Krömer T, Kreft H, Gerold G, Carvajal-Hernández Cl, Heitkamp F (2017) Diversity and composition of herbaceous angiosperms along gradients of elevation and forest-use intensity. PloS one, 12(8)

24. Grytnes JA, Vetaas OR (2002) Species richness and altitude: a comparison between null models and interpolated plant species richness along the Himalayan altitudinal gradient, Nepal. Am Nat 159(3):294-304

25. Holm S (1979) A simple sequentially rejective multiple test procedure. Scandinavian journal of statistics, 65-70

26. Hu A, Yanxia N, Yu G, Han C, He J, He N, Liu S, Shen W, Zhang G (2019) Diurnal temperature variation and plants drive latitudinal patterns in seasonal dynamics of soil microbial community. Frontiers in microbiology 10:674

27. Hussain MS, Sultana A, Khan JA, Khan A (2008) Species composition and community structure of forest stands in Kumaon Himalaya, Uttarakhand, India. Tropical Ecology 49(2):167

28. Jobbágy EG, Jackson RB (2000) The vertical distribution of soil organic carbon and its relation to climate and vegetation. Ecological applications 10(2):423-436

29. Kala CP, Mathur VB (2002) Patterns of plant species distribution in the Trans-Himalayan region of Ladakh, India. J Veg Sci 13(6):751-754 
30. Kammer PM, Schöb C, Eberhard G, Gallina R, Meyer R, Tschanz C (2013) The relationship between soil water storage capacity and plant species diversity in high alpine vegetation. Plant Ecology Diversity 6(3-4):457-466

31. Karl TR, Kukla G, Razuvayev VN, Changery MJ, Quayle RG, H Jr, RR, Easterling, D.R. \& Fu CB (1991) Global warming: Evidence for asymmetric diurnal temperature change. Geophys Res Lett 18(12):2253-2256

32. Korner C (2003) Alpine plant life: functional plant ecology of high mountain ecosystems; with 47 tables. Springer Science \& Business Media

33. Korner C (2007) The use of 'altitude'in ecological research. Trends Ecol Evol 22(11):569-574

34. Korner C, Paulsen J, Spehn EM (2011) A definition of mountains and their bioclimatic belts for global comparisons of biodiversity data. Alp Bot 121:73-78

35. Lebrija-Trejos E, Pérez-García EA, Meave JA, Poorter L, Bongers F (2011) Environmental changes during secondary succession in a tropical dry forest in Mexico. J Trop Ecol 27(5):477-489

36. Lee CB, Chun JH, Song HK, Cho HJ (2013) Altitudinal patterns of plant species richness on the Baekdudaegan Mountains, South Korea: mid-domain effect, area, climate, and Rapoport's rule. Ecol Res 28(1):67-79

37. Legendre P, Gallagher ED (2001) Ecologically meaningful transformations for ordination of species data. Oecologia 129(2):271-280

38. Leigh EG Jr, Davidar P, Dick CW, Terborgh J, Puyravaud JP, ter Steege H, Wright SJ (2004) Why do some tropical forests have so many species of trees? Biotropica 36(4):447-473

39. Lopez-Angulo J, Pescador DS, Sánchez AM, Mihoč MA, Cavieres LA, Escudero A (2018) Determinants of high mountain plant diversity in the Chilean Andes: From regional to local spatial scales. PloS one, 13(7)

40. Mansfield ER, Helms BP (1982) Detecting multicollinearity. The American Statistician 36(3a):158160

41. McCain CM (2007) Could temperature and water availability drive elevational species richness patterns? A global case study for bats. Global Ecology biogeography 16(1):1-13

42. McCune B, Grace JB, Urban DL (2002) Analysis of ecological communities, vol 28. MjM software design, Gleneden Beach

43. Michael TP, Salome PA, Hannah JY, Spencer TR, Sharp EL, McPeek MA, Alonso JM, Ecker JR, McClung CR (2003) Enhanced fitness conferred by naturally occurring variation in the circadian clock. Science 302(5647):1049-1053

44. Minchin PR (1987) An evaluation of the relative robustness of techniques for ecological ordination. In: Theory and models in vegetation science. Springer, Dordrecht, pp 89-107

45. Misra R (1968) Ecology Work Book Oxford and IBH Publishing Co. Calcutta, India Google Scholar 46. Moeslund JE, Arge L, Bøcher PK, Dalgaard T, Svenning JC (2013) Topography as a driver of local terrestrial vascular plant diversity patterns. Nordic Journal of Botany 31(2):129-144 
47. Muller Dombois D, Ellenberg H (1974) Aims and Methods of Vegetation Ecology. John Wiley \& Sons, Inc.

48. Murali KS, Shankar U, Shaanker RU, Ganeshaiah KN, Bawa KS (1996) Extraction of non-timber forest products in the forests of Biligiri Rangan Hills, India. 2. Impact of NTFP extraction on regeneration, population structure, and species composition. Econ Bot 50(3):252-269

49. Negi VS, Maikhuri RK (2017) Forest resources consumption pattern in Govind wildlife sanctuary, western Himalaya, India. J Environ Planning Manage 60(7):1235-1252

50. Negi VS, Joshi BC, Pathak R, Rawal RS, Sekar KC (2018a) Assessment of fuelwood diversity and consumption patterns in cold desert part of Indian Himalaya: implication for conservation and quality of life. J Clean Prod 196:23-31

51. Negi VS, Giri L, Chandra K Sekar (2018b) "Floristic diversity, community composition and structure in Nanda Devi National Park after prohibition of human activities, Western Himalaya, India. Current Science 115(6), 1056-1064

52. Negi VS, Pathak R, Rawal RS, Bhatt ID, Sharma S (2019) Long-term ecological monitoring on forest ecosystems in Indian Himalayan Region: criteria and indicator approach, 102. Ecological Indicators, pp 374-381

53. Newbold T, Hudson LN, Hill SL, Contu S, Lysenko I, Senior RA, Börger L, Bennett DJ, Choimes A, Collen B, Day J (2015) Global effects of land use on local terrestrial biodiversity. Nature 520(7545):45-50

54. O'Brien EM, Field R, Whittaker RJ (2000) Climatic gradients in woody plant (tree and shrub) diversity: water-energy dynamics, residual variation, and topography. Oikos 89(3):588-600

55. Oksanen J, Blanchet FG, Friendly M, Kindt R, Legendre P, McGlinn D, Minchin PR, O'Hara RB, Simpson GL, Solymos P, Stevens MHH (2019) Vegan: Community ecology package [Computer software]

56. Oommen MA, Shanker K (2005) Elevational species richness patterns emerge from multiple local mechanisms in Himalayan woody plants. Ecology 86(11):3039-3047

57. Panda RM, Behera MD, Roy PS, Biradar C (2017) Energy determines broad pattern of plant distribution in Western Himalaya. Ecology evolution 7(24):10850-10860

58. Panda RM, Behera MD, Roy PS, Ramachandran RM (2019) On the relationships between plant species richness and the environment: a case study in Eastern Ghats, India. Environ Monit Assess 191(3):784

59. Partel M, Helm A, Ingerpuu N, Reier Ü, Tuvi EL (2004) Conservation of Northern European plant diversity: the correspondence with soil pH. Biol Conserv 120(4):525-531

60. Partel M, Zobel M, Liira J, Zobel K (2000) Species richness limitations in productive and oligotrophic plant communities. Oikos 90(1):191-193

61. Price M, Gratzer G, Alemayehu Duguma L, Kohler T, Maselli D (2011) Mountain Forests in a Changing World: Realizing Values, Adressing Challenges. Food and Agriculture Organization of the United Nations (FAO) and Centre of Development and Environment (CDE) 
62. Qu M, Wan J, Hao X (2014) Analysis of diurnal air temperature range change in the continental United States. Weather Climate Extremes 4:86-95

63. Ram J, Kumar A, Bhatt J (2004) Plant diversity in six forest types of Uttaranchal, Central Himalaya, India. Current science, 975-978

64. Ramírez-Marcial N, González-Espinosa M, Williams-Linera G (2001) Anthropogenic disturbance and tree diversity in montane rain forests in Chiapas, Mexico. For Ecol Manag 154(1-2):311-326

65. Rawal RS, Pangtey YPS (1994) High altitude forests with special reference to [the] timber line in Kumaun, Central Himalaya. High altitudes of the Himalaya (biogeography, ecology \& conservation)., pp.353-399

66. Rawal RS, Bhatt ID, Sekar KC, Nandi SK (2013) The Himalayan biodiversity: richness, representativeness, uniqueness, and life-support values. GB Pant Institite of Himalaya Environment and Development (GBPIHED), Almora Uttarakhnd

67. Rawal RS, Gairola S, Dhar U (2012) Effects of disturbance intensities on vegetation patterns in oak forests of Kumaun, west Himalaya. J Mt Sci 9(2):157-165

68. Rawal RS, Rawal R, Rawat B, Negi VS, Pathak R (2018) Plant species diversity and rarity patterns along altitude range covering treeline ecotone in Uttarakhand: conservation implications. Tropical Ecology, 59(2)

69. Rawat B (2013) Changes in Vegetation Diversity and Plant Response in Nanda Devi Biosphere Reserve over the Last Two Decades. Thesis,Kumaun University

70. Ricklefs RE (2004) A comprehensive framework for global patterns in biodiversity. Ecology letters $7(1): 1-15$

71. Rozendaal DM, Bongers F, Aide TM, Alvarez-Dávila E, Ascarrunz N, Balvanera P, Becknell JM, Bentos TV, Brancalion PH, Cabral GA, Calvo-Rodriguez S (2019) Biodiversity recovery of Neotropical secondary forests. Sci Adv 5(3):eaau3114

72. Saikia P, Deka J, Bharali S, Kumar A, Tripathi OP, Singha LB, Dayanandan S, Khan ML (2017) Plant diversity patterns and conservation status of eastern Himalayan forests in Arunachal Pradesh, Northeast India. Forest Ecosystems 4(1):28

73. Sarvade S, Gupta B, Singh M (2016) Composition, diversity and distribution of tree species in response to changing soil properties with increasing distance from water source-a case study of Gobind Sagar Reservoir in India. Journal of mountain science 13(3):522-533

74. Saxena AK, Singh SP, Singh JS (1984) Population structure of forests of Kumaun Himalaya: Implications for management. J Environ Manage 19(4):307-324

75. Shah S, Tewari A, Srivastava AK (2011) Influence of aspect and location of stands on biodiversity in a sal mixed broadleaved forest in Kumaun Central Himalaya. Russian Journal of Ecology 42(3):211215

76. Shaheen H, Ullah Z, Khan SM, Harper DM (2012) Species composition and community structure of western Himalayan moist temperate forests in Kashmir. For Ecol Manage 278:138-145 
77. Sharma CM, Mishra AK, Tiwari OP, Krishan R, Rana YS (2017) Effect of altitudinal gradients on forest structure and composition on ridge tops in Garhwal Himalaya. Energy Ecology Environment 2(6):404-417

78. Sharma CM, Mishra AK, Tiwari OP, Krishan R, Rana YS (2018) Regeneration Patterns of Tree Species Along an Elevational Gradient in the Garhwal Himalaya. Mountain research development 38(3):211219

79. Sharma N, Kala CP (2018) Patterns in distribution, population density and uses of medicinal plants along the altitudinal gradient in Dhauladhar mountain range of Indian Himalayas. Curr Sci 114(11):2323

80. Sharma N, Behera MD, Das AP, Panda RM (2019) Plant richness pattern in an elevation gradient in the Eastern Himalaya. Biodivers Conserv 28(8-9):2085-2104

81. Šímová I, Storch D, Keil P, Boyle B, Phillips OL, Enquist BJ (2011) Global species-energy relationship in forest plots: role of abundance, temperature and species climatic tolerances. Glob Ecol Biogeogr 20(6):842-856

82. Simpson EH (1949) Measurement of diversity. nature 163(4148):688-688

83. Singh JS (2006) Sustainable development of the Indian Himalayan region: Linking ecological and. Current science, 90(6)

84. Sinha S, Badola HK, Chhetri B, Gaira KS, Lepcha J, Dhyani PP (2018) Effect of altitude and climate in shaping the forest compositions of Singalila National Park in Khangchendzonga Landscape, Eastern Himalaya, India. Journal of Asia-Pacific Biodiversity 11(2):267-275

85. Spehn EM, Rudmann-Maurer K, Körner C, Maselli D (2010) Mountain biodiversity and global change. Global Mountain Biodiversity Assessment

86. Stark J, Lehman R, Crawford L, Enquist BJ, Blonder B (2017) Does environmental heterogeneity drive functional trait variation? A test in montane and alpine meadows. Oikos 126(11):1650-1659

87. Stein A, Gerstner K, Kreft H (2014) Environmental heterogeneity as a universal driver of species richness across taxa, biomes and spatial scales. Ecology letters 17(7):866-880

88. Stohlgren TJ (2007) Measuring plant diversity: lessons from the field. Oxford University Press, Oxford

89. Thakur S, Negi VS, Pathak R, Dhyani R, Durgapal K, Rawal RS (2020) Indicator based integrated vulnerability assessment of community forests in Indian west Himalaya. For Ecol Manage 457:117674

90. UN (1992) Agenda 21: Chap. 13: Managing fragile ecosystems: sustainable mountain development: United Nations Conference on Environment \& Development, Rio de Janerio

91. Upgupta S, Sharma J, Jayaraman M, Kumar V, Ravindranath NH (2015) Climate change impact and vulnerability assessment of forests in the Indian Western Himalayan region: A case study of Himachal Pradesh, India. Climate Risk Management 10:63-76

92. Wang X, Hao Z, Ye J, Zhang J, Li B, Yao X (2008) Spatial pattern of diversity in an old-growth temperate forest in Northeastern China. Acta oecologica 33(3):345-354 
93. Wang Y, Wu N, Kunze C, Long R, Perlik M (2019) Drivers of Change to Mountain Sustainability in the Hindu Kush Himalaya. In: The Hindu Kush Himalaya Assessment. Springer, Cham, pp 17-56

94. Williams-Linera G, Lorea F (2009) Tree species diversity driven by environmental and anthropogenic factors in tropical dry forest fragments of central Veracruz, Mexico. Biodivers Conserv 18(12):32693293

95. Yang A, Akhtar SS, Amjad M, lqbal S, Jacobsen SE (2016) Growth and physiological responses of quinoa to drought and temperature stress. J Agron Crop Sci 202(6):445-453

96. Zhang JT, Dong Y (2010) Factors affecting species diversity of plant communities and the restoration process in the loess area of China. Ecol Eng 36(3):345-350

97. Zhang JT, Xu B, Li M (2013) Vegetation patterns and species diversity along elevational and disturbance gradients in the Baihua Mountain Reserve, Beijing, China. Mt Res Dev 33(2):170-178

98. Zhang W, Huang D, Wang R, Liu J, Du N (2016) Altitudinal patterns of species diversity and phylogenetic diversity across temperate mountain forests of northern China. PLoS One, 11(7)

99. Zheng X, Wei X, Zhang S (2017) Tree species diversity and identity effects on soil properties in the Huoditang area of the Qinling Mountains, China. Ecosphere 8(3):e01732

100. Zuur AF, leno EN, Elphick CS (2010) A protocol for data exploration to avoid common statistical problems. Methods in ecology evolution 1(1):3-14

\section{Tables}

Due to technical limitations, table 1 is only available as a download in the Supplemental Files section.

\section{Figures}



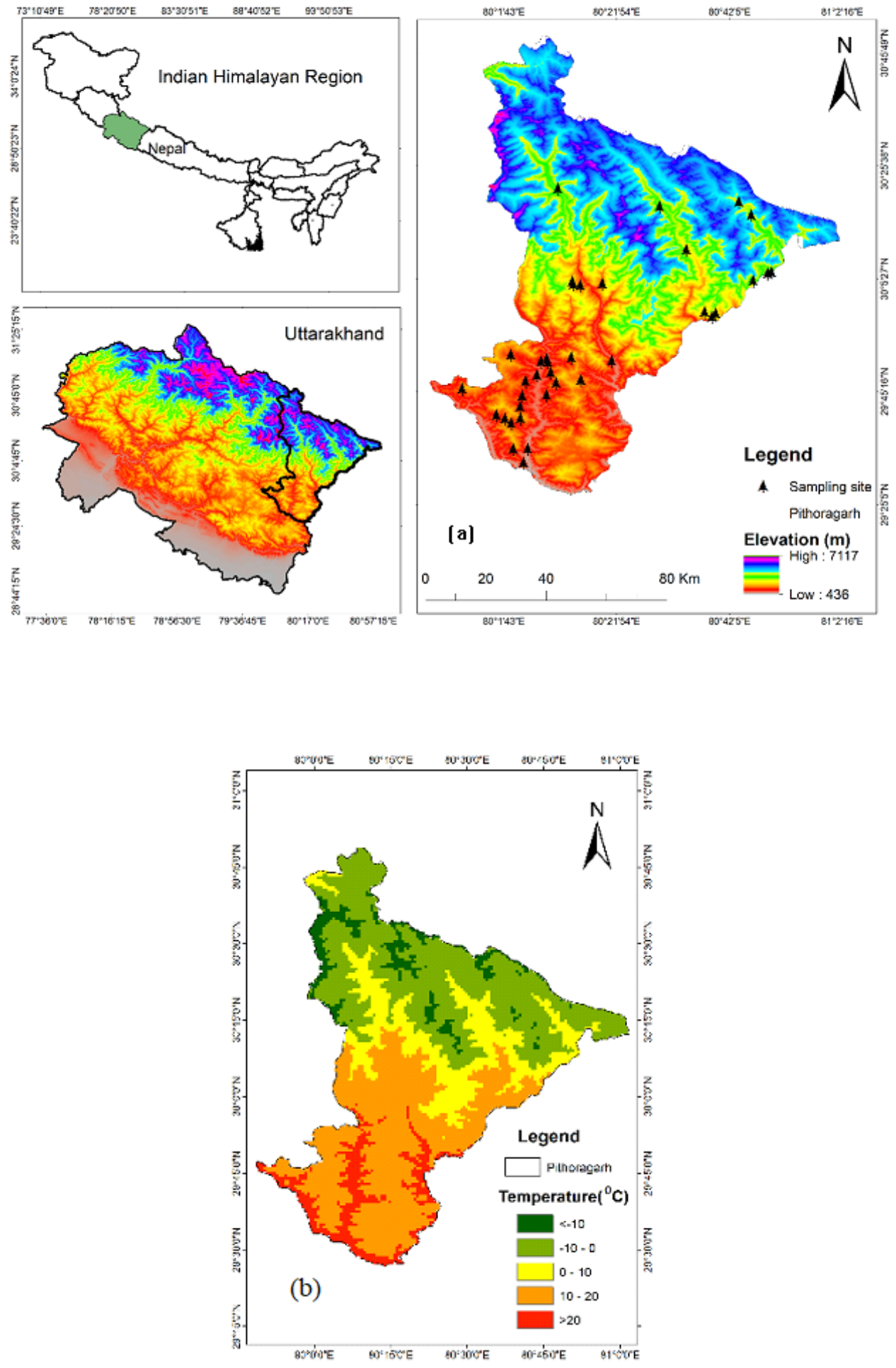

\section{Figure 1}

(a): Location of sampling sites, and (b): temperature zones of Pithoragarh District Note: The designations employed and the presentation of the material on this map do not imply the expression of any opinion whatsoever on the part of Research Square concerning the legal status of any country, territory, city or area or of its authorities, or concerning the delimitation of its frontiers or boundaries. This map has been provided by the authors. 


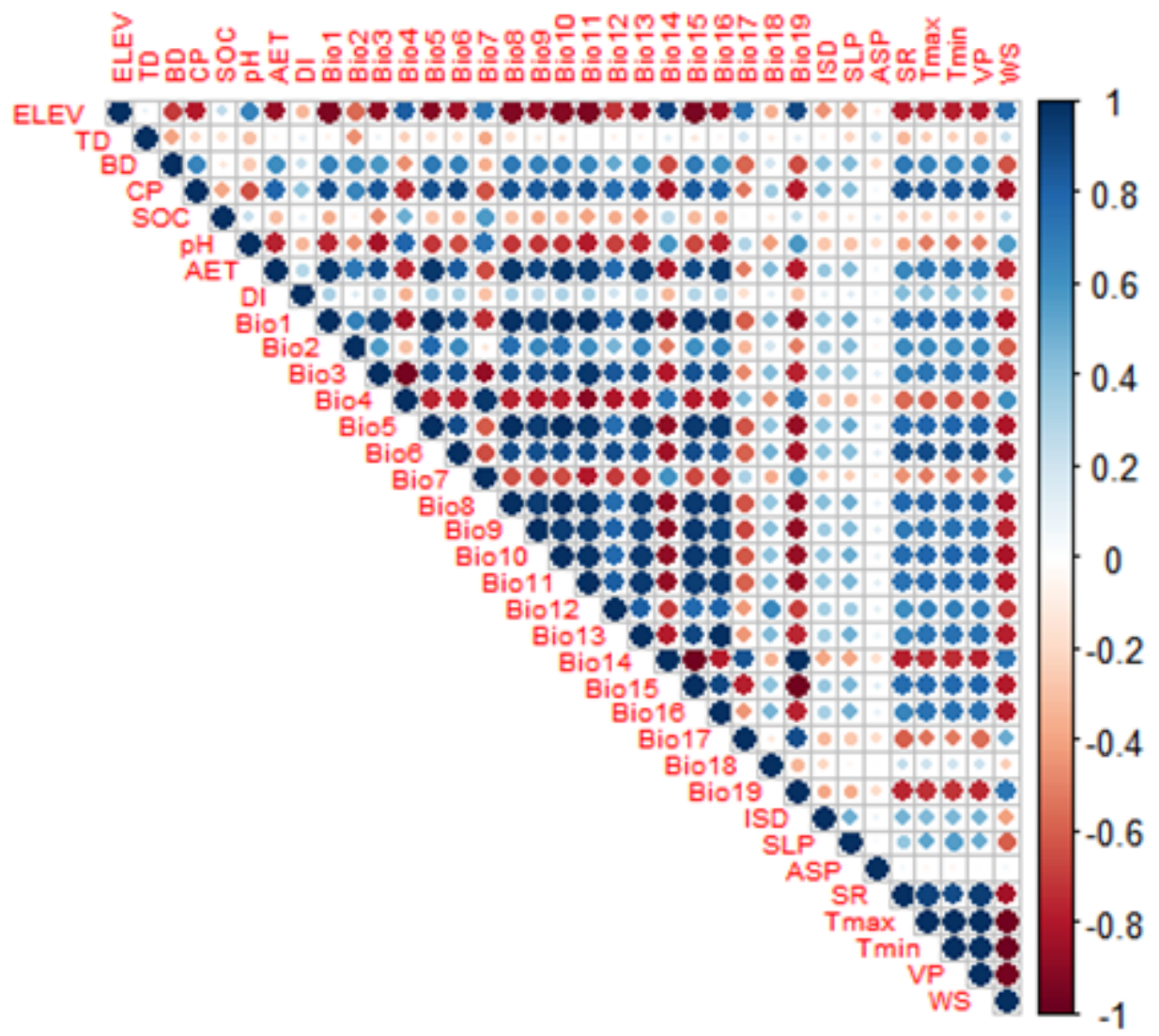

Figure 2

Correlation plot among the environmental factors

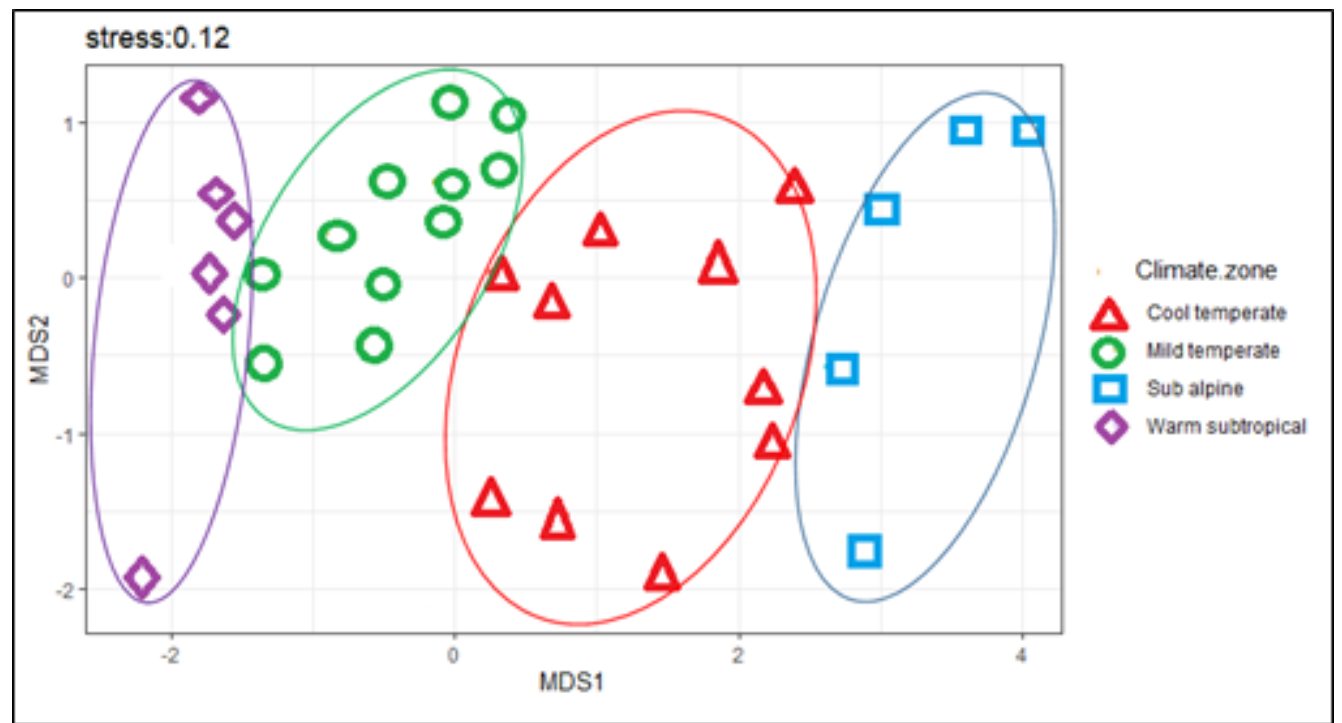

Figure 3

Non-metric multidimensional scaling biplot (NMDS).Bray-Curtis dissimilarity using all species was used in the NMDS; plot stress: 0.12 . 

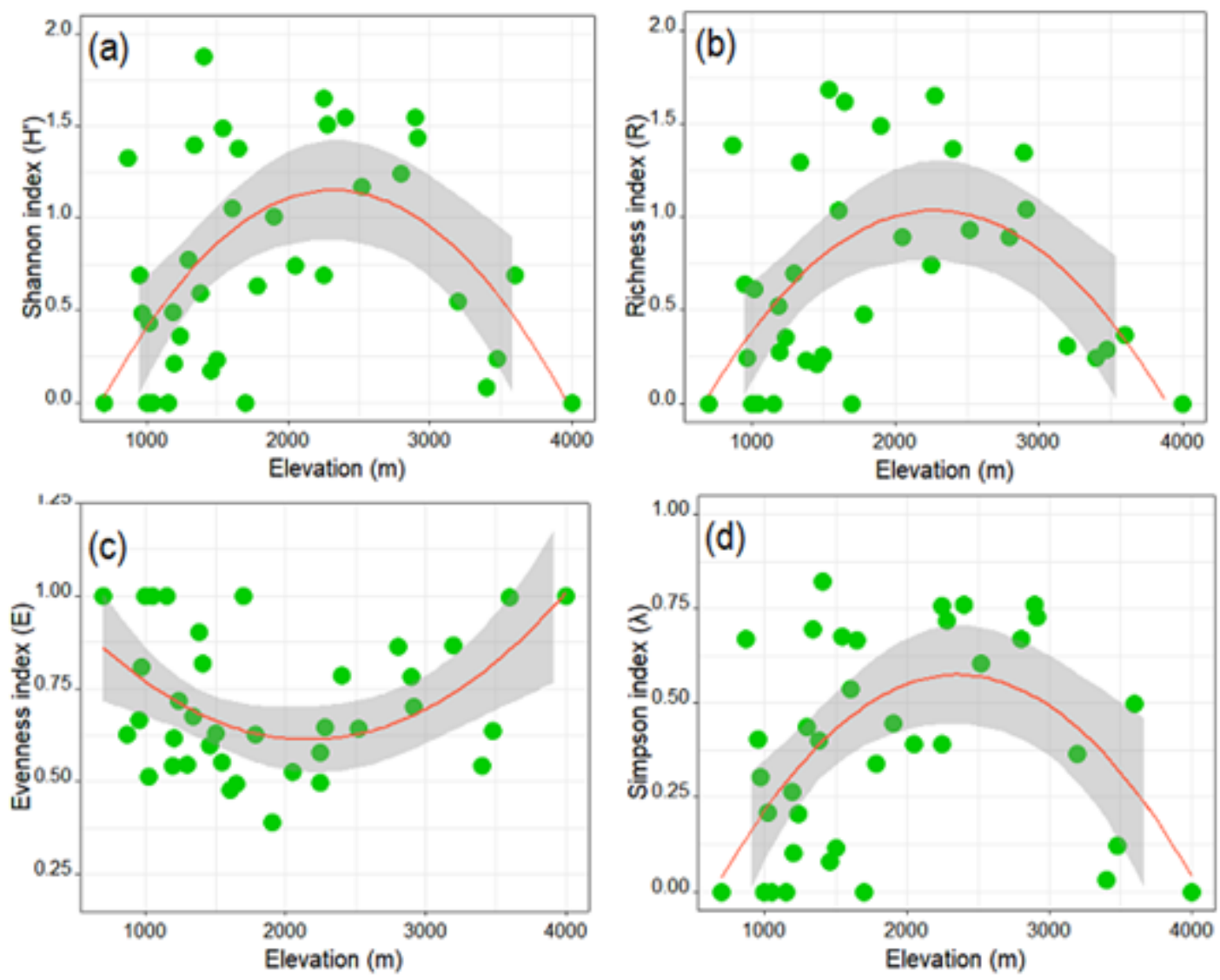

Figure 4

a-d: Variation of a-diversity across the altitudinal gradienta) Shannon index b) Speciesrichness index, c) Evenness index. d) and Simpson diversity index, Nonlinear regressions and 95\% confidence interval are depictedas lines and shaded areas, respectively 

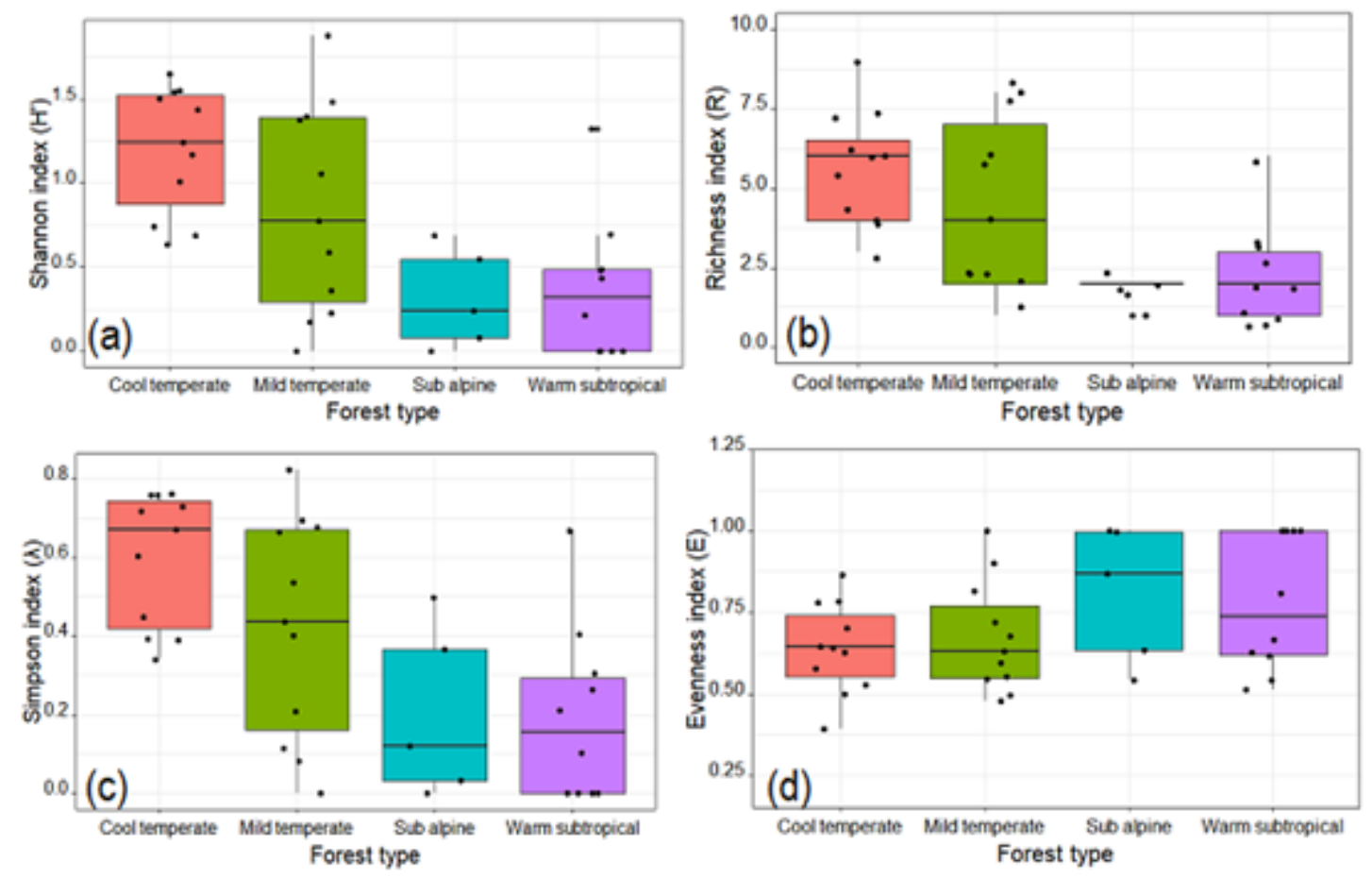

\section{Figure 5}

a-d: Boxplot showing descriptive statistics of a-diversity indices across different forest typesa) Shannon index b) Speciesrichness index, c) Evenness index. d) and Simpson diversity index,

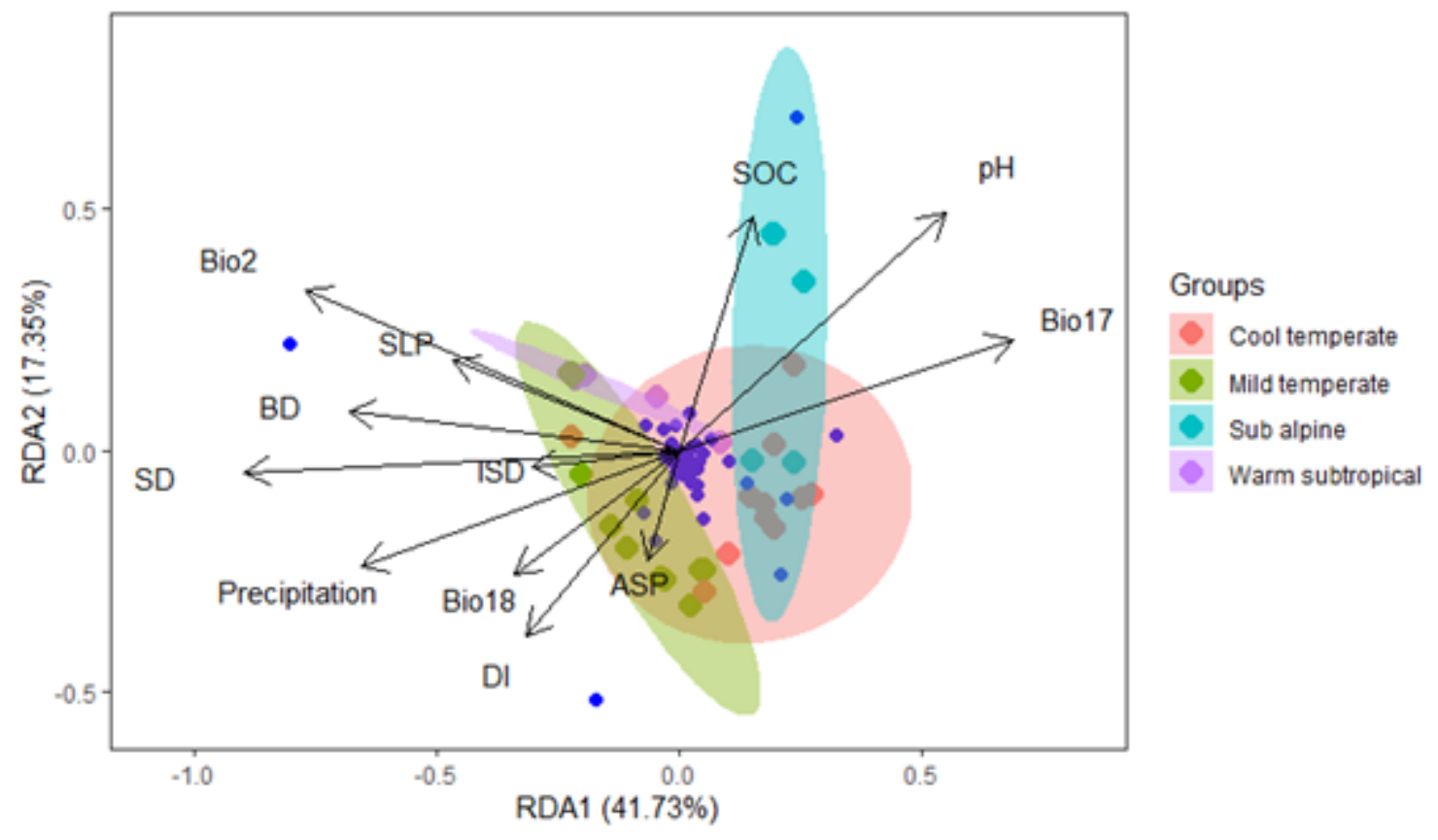

Figure 6

Ordination diagram showing the results of RDA of the species composition and environment variables of study sites. The direction of the arrow indicating a positive or negative correlation among the environmental factors with the ordination axes. The length of the arrow reflects the strength of correlation 
between the environmental factors and the distribution pattern of diversity indices, with long lines indicating strong correlations.

\section{Supplementary Files}

This is a list of supplementary files associated with this preprint. Click to download.

- Table.doc

- Supplementarymaterial.doc 